\title{
MEDITERRANEAN SEA FRY; A SOURCE OF ISOPOD INFESTATION PROBLEM IN EGYPT WITH REFERENCE TO THE EFFECT OF SALINITY AND TEMPERATURE ON THE SURVIVAL OF LIVONECA REDMANII (ISOPODA: CYMOTHOIDAE) JUVENILE STAGES. \\ By
}

\author{
NISREEN E. MAHMOUD ${ }^{1 *}$, MAGDY M. FAHMY ${ }^{1}$, MAI M. ABUOWARDA ${ }^{1,}$ MANAL \\ M. ZAKI ${ }^{2}$, EMAN M. ISMAIL, ${ }^{2}$ AND ELSHAIMAA S. ISMAEL ${ }^{2}$ \\ Department of Parasitolgy ${ }^{1}$, and Department of Veterinary Hygiene and Management \\ Faculty of Veterinary Medicine, Cairo University, Giza, Egypt \\ ( ${ }^{\star}$ Correspondence: Mahmoud NE drnisreene@hotmail.com)
}

\section{Abstract}

Parasitic isopods have received considerable attention as they cause series impacts on their hosts either alone or with other environmental stresses such as water pollution. The present study investigated the infestation status with isopods among the fry collected from the natural sources.Also to demonstrate the effects of different salinity and temperature combination on the survival rates of the identified isopods under the laboratory conditions. In March 2017, a total of 16 thousand mugiliid fry were sampled from The Fry Collection center at Al Behera Governorate ,Egypt and examined for the presence of isopods .Samples were found infested with a rate of $10.6 \%$, the result which practically documented that isopods were introduced into lake Qarun through dumping millions of infected fry from this source without biosecurity procedures. The isolated juvenile isopods were morphologically and molecularly identified as Livoneca redmanii species by using 16S rRNA gene and recorded in the GenBank with accession number: MK584629. The effects of variables of salinity/ temperature combination on the survival\% of the identified juveniles showed that the best survival rate(100\%) was recorded in salinity $15-20 \%$ at temperature $25^{\circ} \mathrm{C}$ while the lethal combination was in salinity $10,20,50$ and $60 \%$ at temperature $35^{\circ} \mathrm{C}$. Statistical analysis using A-two way ANOVA indicated a significant interaction between the effect of different degree of temperature and variance of salinity\% on the survival of $L$. redmanii juveniles. Analysis of one way ANOVA indicated that the most effective temperature of overall mean temperature affected on survival of juvenile stage was $35 \mathrm{C}^{0}$ while the most effective salinity percentage on survival of Juvenile from overall mean of salinity $\%$ was $10 \%$.Results of this study provided applicable procedures which can be recommended as a precaution measures and for eliminating the isopod juvenile stages among the mugiliid fry.

Key words: Mugliid Fry; Cymothoid isopod; Livonica redmanii; Salinity, Temperature.

\section{Introduction}

Cymothoid isopods are large fierce looking ectoparasitic crustaceans. They are protandrous hermaphrodites inhabiting brackish water, freshwater and marine environments (Tansel and Fatih, 2012). They are recorded worldwide and are mostly host and site specific (Saito et al 2014). Cymothoid species affect body surface, buccal cavity and branchial cavity of their host causing considerable tissue damages and even mortalities (Trilles and Bariche 2006). The life cycle of cymothoids is biphasic. Adult females are attached permanently to fish host and give birth to free-swimming mancae with six pairs of legs which developed into juvenile stages (Lindsay and Moran 1976) and (San- difer and Kerby, 1983).

Infestation with isopod parasites was reported in marine Egyptian Coasts and Lakes (Noor El-Deen et al, 2013; Youssef et al, 2014; Maather and Abdel-Mawla, 2015; Abdel-Latif, 2016). In 2015, Lake Qarun (an inland closed salt water lake at Fayoum Governorate), which was exposed to a catastrophic invasion of several species of isopods causing fish mortalities and destroyied the fish stocks in the lake (Mahmoud et al, 2016; Elgendy et al, 2018; Helal and Youssef, 2018). The route by which isopods were introduced to Lake Qarun was questionable and needed practical field investigations to be proved. In Egypt, the sources of obtaining fry included hatcheries and natural 
sources where the fry (mainly of mugiliid species) were captured from the seas and collected in Fry collection stations to be transported and officially delivered to supply the lakes annually. Studies for isopod control have been also conducted including chemical treatments (Shaheen et al, 2017) and biological trials (Mahmoud et al, 2017). Salinity and temperature are considered as the most important factors that physiologically affect the viability of marine organisms (Coineau, 1985; Aktas et al, 2004; Lemaire et $a l, 2002)$ and the degree of tolerance for both factors varied among different parasitic species particularly the crustaceans (Jansen, 1970; Jones 1972; Albuquerque, 2009; Thiyagarajan et al, 2003).

This study aimed to determine the infestation status of the mugiliid fry collected from the natural sources with isopod species. Also to demonstrate the effects of different salinity and temperature combination on the survival rates of the detected isopods under the laboratory conditions in order to record the most effective methods for controlling and preventing infestation spread through fry transportation.

\section{Materials and methods}

Collection of samples: In March 2017, a scientific documented field visits was done by the research team to the Fry Collection Station at Al Meadeyya Region, Al Beheira Governorate, Egypt (Fig. 1) where the mugiliid fry officially received to be transported to supply different lakes and fish farms. At the Station, a total of ten thousand randomly collected mugiliid fry units were examined on spot for the presence of isopod species. The fry were collected by fishermen by using nets of fine mesh size from the Boughaz Al Meadeyya (a channel of $20 \mathrm{~m}$ wide, $100 \mathrm{~m}$ long and $2 \mathrm{~m}$ deep) in connection between Lake Edko and Mediterranean Sea Coast (Waheed et al, 2013) ( Fig. 1 B). In this location, the temperature and salinity of water were measured in situ using portable optical TDS salinometer/refractometer. The isolated isopods and additional 6 thou- sand randomly collected fry samples within their original sub-surface water were transported in separate containers (F. 2B) supplied with oxygen to the laboratory as samples were kept in their original water in aerated glass aquaria for further investigations.

Morphological identification of the isolated isopod species: Isopods were measured to the nearest millimeters $(\mathrm{mm})$, photographed using a digital camera (Cannon of 12 mega pixels) and morphologically identified according to (Bruce, 1990; Jones et al, 2008; Mahmoud et al, 2017)

Molecular identification: The DNA extraction from isolated isopods was extracted using DNeasy Tissue Kit (Qiagen, Germany) according to the manufacturer's instructions. Extracted DNAs were stored at $-20^{\circ} \mathrm{C}$ till used. Extracted DNAs from Juvenile stages were using the primers, Fish-F1 (5 AGCCCTGTTCAATGGGATTA -3') and Fish-R2 (5 TCCCTGGGGTAGTTTCATCTT -3`) to amplify a $417 \mathrm{bp}$ fragment of the $16 \mathrm{~S}$ ribosomal RNA gene (Thangara et al, 2014). TPCR reaction volume was $25 \mu 1$ and each reaction mixture contained $12.5 \mu \mathrm{l}$ of $2 \mathrm{X}$ PCR Hot-StarTaq ${ }^{\circledR}$ master mix (Qiagen, Germany), $0.1 \mu \mathrm{M}$ of each primer, $1 \mu \mathrm{l}$ of DNA template and completed up to $25 \mu 1$ with nuclease free water. PCR assay was performed in T100 ${ }^{\mathrm{TM}}$ Thermal Cycler (Bio-Rad, USA) under the following conditions: initial denaturation at $94^{\circ} \mathrm{C}$ for $2 \mathrm{~min}$ followed by 35 cycles of $1 \mathrm{~min}$ at $95^{\circ} \mathrm{C}$, annealing at $54^{\circ} \mathrm{C}$ for $30 \mathrm{sec}$, an extension at $72^{\circ} \mathrm{C}$ for $1 \mathrm{~min}$ and then a final extension step of $10 \mathrm{~min}$ at $72^{\circ} \mathrm{C}$. Nuclease free water was used as a negative control.

DNA sequencing: PCR products of positive samples were purified using a QIA quick purification kit (Qiagen, Germany) for sequencing using Big Dye Terminator V3.1 kit in ABI 3500 Genetic Analyzer (Applied Biosystems, USA). The sequences were compared with those available in the GenBank using a BLAST server on the NCBI website. Nucleotide Sequence: partial sequences of the isopod species 16SrRNAgene were sub- 
mitted to GenBank.

Experiment procedure: For demonstrating the impacts of the variable salinity/ temperature combination on the survival of the isolated isopod species under laboratory conditions, an experiment was designed following (Albuquerque et al, 2009) with some modifications. Groups of 15 isopods (in 3 replicates of 5 parasites each) were put in $250 \mathrm{ml}$ of the tested salinity in $500 \mathrm{ml}$ capacity glass beakers and exposed to variable salinity/temperature combination. Tested isopods were allowed one minute after exposure for adaptation with the surrounding, then the beakers were covered with transparent thin sheath (to reduce change of water salinity by evaporation) and supplied with an aerator tubes. The experiment included 5 temperature degree $\left(15,20,25,30 \& 35^{\circ} \mathrm{C}\right)$ and eight salinities $(15,20,25,30,35,40,50 \& 60 \%)$ to verify a total of 40 salinity/ temperature combination. Salinitiy less than the sea water were prepared using distilled water and higher one was by evaporating sea water at $50^{\circ} \mathrm{C}$. Salinity and temperature were monitored by using digital TDS salinometer/ refractometer. Beakers were examined after $6 \mathrm{hr}, 12 \mathrm{hr}, \& 24 \mathrm{hr}$ of exposure then every $24 \mathrm{hr}$ till $72 \mathrm{hr}$. Isopods were neither with visible movement nor response to the external touch by needle under binocular microscope were dead and removed (Johansen, 1999). Control groups were kept in salinity 33\% and temperature $25^{\circ} \mathrm{C}$ as these are the average that the isolated isopods were naturally exposed in field at time of collection. Statistical analysis: Numerical data for different grade of temperature, salinity and survival $\%$ were carried out using the two-way ANOVA test (Sokal and Rohlf, 1995). Further statistical analysis of the numerical differences in survival of the isopod species using variance of salinity percentages was conducted by using the SPSS 20.0 statistics software for determined significant differences at $\mathrm{P}<0.05$.

\section{Results}

Examination of 16 thousand mugiliid fry randomly collected from the Al Meadeyya Fry Collection Station showed free swimming isopod stages with the rate of $10.6 \%$.

The detected isopod species was identified taxonomically as L. redmanii juvenile stages (Fig. 2A). They were of body length ranged from $10-16 \mathrm{~mm}$ (mean $13 \mathrm{~mm}$ ) having pale translucent grayish color with brown chromatophores on the body dorsal aspect. The juvenile stage has large oval eyes, six pairs of legs and the pleopods provided with fine setae.

The isolated isopod species revealed amplicon with molecular weight $417 \mathrm{bp}$. The sequence analysis explained that the samples were $96 \%$ identical with Livoneca redmanii. This identified species was recorded in the GenBank on the NCBI with accession number: MK584629.

Using of 40 salinity/temperature combination under laboratory conditions revealed that the survival rate of $100 \%$ for the juveniles of $L$. redmanii was recorded at temperature $15^{\circ} \mathrm{C}, 20^{\circ} \mathrm{C} \& 25^{\circ} \mathrm{C}$ where the tested juveniles able to resist salinity of 20\% $-40 \%$ (till $72 \mathrm{hr}$ exposure). The lower lethal salinity of $50 \%$ of the tested juveniles $\left(\mathrm{LS}_{\mathbf{5 0}}\right.$ ) was $20 \%$ at $20^{\circ} \mathrm{C}$ while the higher $\mathrm{LS}_{\mathbf{5 0}}$ was $25 \%$ at $30^{\circ} \mathrm{C}$ (after $48 \mathrm{hr}$ ). At temperature $30^{\circ} \mathrm{C}$, the mortality rate was $100 \%$ at salinity $10 \%$ and $60 \%$ (extreme salinities) after $24 \mathrm{hr}$, while the juveniles resisted the salinity of $20 \%$ to $50 \%$ (survival rate ranged from 20 $50 \%$ ). At temperature $35^{\circ} \mathrm{C}$, only $10 \%$ of the exposed juveniles can resist the salinity range of $20-40 \%$ while all juveniles $(100 \%)$ died in the S 10\%, 20\%, 50\% and 60\%. Mortality was $0 \%$ in control group till the end of experiment (72hr), $6 \mathrm{hr}$ and $12 \mathrm{hr}$ of exposure for all combination and also after $48 \mathrm{hr}$ to $72 \mathrm{hr}$ exposure.

A two-way ANOVA was conducted to verify the effect of different grades of temperature and salinity level on the survival of the juvenile stage of $L$. redmanii under laboratory conditions. Result indicated a statistically significant interaction between the effect of different grading of temperature 
and variance of salinity\% on survival of the juvenile species, $\mathrm{F}(28,80)=3.69, \mathrm{P}=0.00$.

The effect of temperature, salinity and their interaction gave significant effect on the percentage of survival of juvenile stage of L. redmanii $(\mathrm{P}=0.00)$. It is important to concern by salinity*temperature interaction on survival of juvenile stages was zero at salinity* temperature interaction was $10 \%$ $* 30^{\circ} \mathrm{C}, 60 \% * 30^{\circ} \mathrm{C}, 10 \% * 35^{\circ} \mathrm{C}, 20 \% * 35^{\circ} \mathrm{C}$, $50 \% * 35^{\circ} \mathrm{C}$ and $60 \% * 35^{\circ} \mathrm{C}$ respectively (Tab.1, Ch. 1). Analysis of one way ANOVA using Duncan test explained significant difference between overall mean differences of temperature and salinity $(\mathrm{P}<0.05)$. The most effective temperature of overall mean temperature affected on survival of juvenile stage was $35^{\circ} \mathrm{C}(10 \pm 2.63)$, but without significant difference at $p<0.05$ between effects at $15^{\circ} \mathrm{C} \& 25^{\circ} \mathrm{C}(82.5 \pm 5.81 \& 79.17 \pm 4.88$ respectively).

The best salinity affected juvenile survival was $10 \%$ (20 \pm 10.9$)$, but without significant difference between salinity $20 \% \& 25 \%$ (54.67 $\pm 17.17 .1 \& 58.67 \pm 14.8$ respectively) and between $30 \% \& 35 \%(70.67 \pm 17.9 \&$ $69.33 \pm 17.4$ respectively) at $p<0.05$ (Tab. 1 , Ch. 1 \& 2).

Table 1: Effects of variance of temperature and level of salinity $\%$ on survival of juvenile stage of L. redmanii

\begin{tabular}{|c|c|c|c|c|c|c|c|c|c|c|}
\hline Salinity $\%$ & 10 & 20 & 25 & 30 & 35 & 40 & 50 & \multicolumn{4}{|c|}{60} & $\begin{array}{c}\text { Overall mean of } \\
\text { Temp. }\end{array}$ \\
\hline Temp. & \multicolumn{7}{|c|}{$\%$ of survival of juvenile stage of Livonecaredmani } \\
\hline 15 & $20 \pm 11.5^{\mathrm{a}}$ & $100 \pm 0.0^{\mathrm{c}}$ & $100 \pm 0.0^{\mathrm{c}}$ & $100 \pm 0.0^{\mathrm{c}}$ & $100 \pm 0.0^{\mathrm{c}}$ & $86.67 \pm 6.67^{\mathrm{bc}}$ & $86.67 \pm 13.3^{\mathrm{bc}}$ & $66.67 \pm 6.7^{\mathrm{b}}$ & $82.5 \pm 5.81^{\mathrm{D}}$ \\
\hline 20 & $20 \pm 11.5^{\mathrm{a}}$ & $53.33 \pm 6.7^{\mathrm{b}}$ & $53.33 \pm 6.6^{\mathrm{b}}$ & $100 \pm 0.0^{\mathrm{d}}$ & $93.33 \pm 6.7^{\mathrm{d}}$ & $86.67 \pm 6.6^{\mathrm{cd}}$ & $80 \pm 11.5^{\mathrm{cd}}$ & $66.67 \pm 6.7^{\mathrm{bc}}$ & $69.17 \pm 5.64^{\mathrm{C}}$ \\
\hline 25 & $60 \pm 11.5^{\mathrm{ab}}$ & $80 \pm 11.54^{\mathrm{bc}}$ & $80 \pm 11.5^{\mathrm{bc}}$ & $100 \pm 0.0^{\mathrm{c}}$ & $100 \pm 0.0^{\mathrm{c}}$ & $100 \pm 0.0^{\mathrm{c}}$ & $73.33 \pm 6.7^{\mathrm{bc}}$ & $40 \pm 11.5^{\mathrm{a}}$ & $79.17 \pm 4.88^{\mathrm{D}}$ \\
\hline 30 & $0 \pm 0.0^{\mathrm{a}}$ & $40 \pm 11.5^{\mathrm{b}}$ & $46.67 \pm 13.3^{\mathrm{b}}$ & $26.67 \pm 6.6^{\mathrm{ab}}$ & $26.7 \pm 6.67^{\mathrm{ab}}$ & $33.3 \pm 6.67^{\mathrm{b}}$ & $20 \pm 11.5^{\mathrm{ab}}$ & $0 \pm 0.0^{\mathrm{a}}$ & $24.17 \pm 4.1^{\mathrm{B}}$ \\
\hline Overall salinity\% & $0 \pm 0.0^{\mathrm{a}}$ & $0 \pm 0.0^{\mathrm{a}}$ & $13.3 \pm 6.6^{\mathrm{ab}}$ & $26.67 \pm 6.7^{\mathrm{b}}$ & $26.67 \pm 6.7^{\mathrm{b}}$ & $13.3 \pm 6.6^{\mathrm{ab}}$ & $0 \pm 0.0^{\mathrm{a}}$ & $0 \pm 0.0^{\mathrm{a}}$ & $10 \pm 2.63^{\mathrm{A}}$ \\
\hline
\end{tabular}

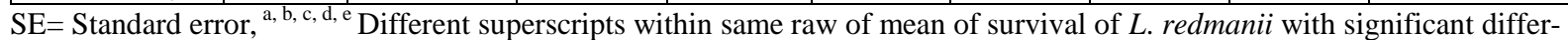
ence at $P<0.05$. A, B, C, D Different superscripts within same column (overall mean of temperature) indicate significant difference at $P<0.05$.

\section{Discussion}

Examination of the mugiliid fry from the collection station revealed high infestation rate $(10.6 \%)$ with free swimming juvenile isopods identified morphologically and molecularly as Livoneca redmanii. This species was recorded as the most abundant species invaded Lake Qarun (Mahmoud et al, 2017; Helal and Youssef, 2018). The present of high rate of isopods among the officially transported mugillid fry collected from the Mediterranean Sea confirmed that the invasive isopods were introduced into Lake Qarun through dumping fry from infested source without examination or biosecurity program. Among the examined fry, no adult stages of $L$. redmanii were recorded as the adult females and males of this species are mostly attached in pairs in the branchial cavity of their hosts (Sandifer and Kerby, 1983) .This result agreed with Eissa et al. (2012) and Kayiş and Ceylan (2011).

In the present study, L. redmanii juveniles showed moderate to high tolerance survival from 50 to $100 \%$ ) of the tested species to the salinity between 20 to $60 \%$ at temperature degree from 15 to $25^{\circ} \mathrm{C}$. The tolerance decreased (survival $0 \%$ ) with increasing temperature (up to $35^{\circ} \mathrm{C}$ ). The same agreed with Sjoeberg (1967) and Jansen (1970) for adults of the isopod Jaera albifrons and Sphaeroma hookeri respectively. Juveniles of $L$. redmanii resisted low temperature $\left(15^{\circ} \mathrm{C}\right)$ rather than high $\left(35^{\circ} \mathrm{C}\right)$ and tolerated better the salinity variation at low temperature. Also Kinne (1964) mentioned that temperature can change the salinity effect and vice versa. Death of the isopod juveniles might be due to the disturbance of their osmo-regulatory system (Lucu and Towels 2002).

The juveniles showed lowest survival\% at high temperature in combination with extreme low and high salinity\%. But, Albuquerque et al. (2009) found that for the isopod Coxicerberus ramosae adults, lowest survival rate was at low temperature/ low salinity combination. Variation might be due to species or stages difference (Charmantier and Charmantier-Daures, 1994) who found that euryhalinity increased progressively in 
isopod juvenile stages to maximum in the latest stages and even up to adults. Other factors may also be the parasite size, water parameters or water pollution.

In the present study, the best combination for $100 \%$ survival of $L$. redmanii juveniles was at $15^{\circ} \mathrm{C}$ with salinity from 20 to $35 \%$, at $25^{\circ} \mathrm{C}$ with salinity from 30 to $40 \%$ and at $20^{\circ} \mathrm{C}$ with salinity $30 \%$. This showed a high level of euryhalinity for $L$. redmanii juvenile stages. No mortality after $6 \mathrm{hr} \& 12 \mathrm{hr}$ in all combination after $48 \mathrm{hr}$ to $72 \mathrm{hr}$ of exposure showed that $L$. redmanii juveniles have high degree of adaptation so this was the cause of the isopod abundance in Qarun Lake environment.

Unfortunately, the natural field condition of salinity/ temperature during the mugiliid fry transportation season (from February to April) lies within the same range of the best combination for $100 \%$ survival of tisopod juvenile species that promoted the fish infestation within the water surfaces if received infested fry from natural resources specially that of salt or marine nature.

\section{Conclusion}

The present study practically proved that, infected fry from natural sources played the main role in transmitting isopod infestation. Also the results indicated that, the combination of salinity $10 \% / 35^{\circ} \mathrm{C}$ was of lethal effect on the isopod juvenile stages $(100 \%$ mortality after 24-30 hours expos- ure), so exposure of the mugiliid fry to this lethal temperature/ salinity combination as a precaution measures and method of elimination of the isopod juvenile stages of L. redmanii among them was recommended to be applied.

\section{References}

Abdel-Latif, HM, 2016: Cymothoid parasite, Nerocilaorbigni inflects great losses on Tilapia zilli in Lake Qarun at Fayoum Governorate. Int. J. Innov. Stud. Aqua. Biol. Fish. 2, 3:1-9.

Aktas, M, Eroldogan, OT, Kumlus, M. 2004: Combined effects of temperature and salinity on egg hatching rate and incubation time of $\mathrm{Pe}$ naeussemisulcatus (Decapoda: Penaidae). Isr. J.
Aqua. Bamidgeh 56, 2:126-30.

Albuquerque, EF, Meurer, B, Genofre, GC, 2009: Effects of Temperature and Salinity on the Survival Rates of Coxicerberusramosae (Albuquerque, 1978), an Interstitial Isopod of a Sandy Beach on the Coast of Brazil. Braz. Arch. Biol. Technol. 52:1179-87.

Bruce, NL, 1990: The genera Catoessa, Elthusa, Enispa, Ichthyozenus, Idusa, Livoneca, and Norileca n. gen. (Isopoda, Cymothoidae), crustacean parasites of marine fishes, with descriptions of Eastern Australian species. Records of the Australian Museum 42:247-300.

Charmantier, G, CharmantierDaures, M. 1994: Onteogeny of osmoregulation and salinity tolerance in the isopod crustacean Sphaeromaserratum. Marine Ecol. 114, 1:93-101

Coineau, N, 1985: Colonisation du milieu souterrain continental par les organismesd'origine marine moyend'acces par le milieu interstitiel. Bull. Soc. Biosp. 8:26-30.

Eissa, IAM, El-Lamie, M, Zakai, M, 2012: Studies on crustacean diseases of seabass, Morone-Labrax, in Suez Canal, Ismailia Governorate. Life Sci. J. 9, 3:512-8.

Elgendy, MY, Hassan, AM, Abdel Zaher, M F, Abbas, HH, Soliman, WS, et al, 2018: Nerocila bivittata massive infestations in Tilapia zillii with emphasis on hematological and histopathological changes. Asian J. Sci. Res. 11:134-44.

Helal, AM, Yousef, OE, 2018: Infestation study of Livoneca redmanii (Isopoda, Cymothoidae) on Mugil cephalus in Lake Qarun, Egypt. Egypt. Acad. J. Biol. Sci. (B. Zool.), 10, 1:1-17.

Jansen, KP, 1970: Effect of temperature and salinity on survival and reproduction in Baltic populations of Sphaeromahookeri Leach, 1814 and S. rugicauda Leach, 1814 (Isopoda). Ophelia 7:177-84

Johansen, PO, 1999: Observations on the tolerance of Natatolana borealis (Lilljeborg) (Crustacea, Isopoda) to reduced salinity. Sarsia 84, 2:169-72.

Jones, MB, 1972: Effects of salinity on the survival of the Jaeraalbifrons Leach group of species (Crustacea: Isopoda). J. exp. Mar. Biol. Ecol. 9:231-7.

Jones, CM, Miller, TL, Grutter, AS, Cribb, T H, 2008: Natatory-stage cymothoid isopods: description, molecular identification and evolution of attachment. Int. J. Parasitol. 38:477-91. 
Kayiş, A, Ceylan, Y, 2011: First report of Nerocila orbigyni (Crustacea, Isopoda, Cymothoidae) on Soleasolea (Teleostei, Soleidae) from Turkish Sea. Turk. J. Fish. Aqua. Sci. 11:167-9.

Kinne, O, 1964: The effects of temperature and salinity on marine and brackish water animals. II- Salinity and temperature salinity compinations: Oceanography and Marine Biology Ann. Rev. 2: 281-339.

Lemaire, P, Bernard, E, Martinez-Paz, J, 2002: Combined effect of temperature and salinity on osmoregulation of juvenile and sub-adult Penaeussty lirostris. Aquacult. 209, 1/4:307-17.

Lindsay, JA, Moran, RL, 1976: Relationships of parasitic isopods Lironeca ovalis and Olenciraprae gustator to marine fish hosts in Delaware Bay. Trans. Am. Fish. Soc. 2:327-32.

Lucu, C, Towle, W, 2002: $\mathrm{Na}^{++} \mathrm{K}^{+}$-ATPase in gills of aquatic crustacean. Comp. Biochem, $\mathrm{Ph}-$ ysiol. 135, 2:195-214.

Maather, MM, Abdel-Mawla, HI, 2015: Isopod infestation in relation to vibriosis of some marine fishes. Egypt. J. Aquac. 5, 2:13-26.

Mahmoud, NE, Fahmy, MM, Abuowarda, M M, Khattab, MS, 2016: Parasitic Cymothoid Isopods and their Impacts in Commercially Important fishes from Lake Qarun, Egypt. Int. J. Chem. Tech. Res. 9, 12:221-9.

Mahmoud, NE, Fahmy, MM, Abuowarda, M M, Khattab, MS, 2017: An investigation of cymothoid isopod invasion in Lake Qarun fishes with preliminary trial for biological control. Int. J. Chem. Tech. Res. 10:409-16.

Noor El-Deen, AE, Zaki, MS, Shalaby, IS, 2013: Some investigations observed in culture seabass, Dicentrarchus labrax infested with Lernanthropus kroyeri and Nerocila orbignyi exposed to pollution during different seasons at Damietta Governorate. Life Sci. J. 10, 3:1877-84.

Saito, N, Yamauchi, T, Ariyama, H, Hoshino, H, 2014: Descriptions and ecological notes of free-swimming forms of cymothoid isopods (Crustacea: Peracarida) collected in two coastal waters of Japan. Crust. Res. 43:1-16.

Sandifer, PA, Kerby, JH, 1983: Early life history and biology of the common fish parasite,
Lironecaovalis (Say) (Isopoda, Cymothoidae). Estuaries 6:420-5.

Sokal, RR, Rohlf, FJ, 1995: Biometry. In: Principles and Practice of Statistics in Biological Research. $3^{\text {rd }}$ Ed., W.H. Freeman Co., New York. Shaheen, AA, Abd El-Latif, AM, Elmadawy, RS, Noor Eldeen, AE, 2017: Isopodiosis in some fishes from Egyptian Qaroun Lake: Prevalence, identification, pathology and in vitro trials to get rid of it. Res. J. Pharm. Bio. Chem. Sci. 8, 1:1971-8

Sjöeberg, B, 1967: On the ecology of the Jaera albifrons group (Isopoda). Sarsia 29: 321-48.

Tansel, T, Fatih, P, 2012: Ectoparasitic sea lice, Caligusminimus (Otto 1821, Copepoda: Caligidae) on brawn wrasse, Labrusmerula L., in Izmir Bay, Aegean Sea. J. Anim. Sci. 11, 38:20811.

Thangara, M, Saranya, S, Divya, S, Ramanadevi, V, Subburaj, J, 2014: Molecular phylogenetic status of some marine Cymothoid isopods in southeast coast of India. Indian J. GeoMarine Sci. 43, 2:271-6.

Trilles, JP, Bariche, M, 2006: First record of the Indo-Pacific Cymothoaindica (Crustacea: Isopoda: Cymothoidae), a Lessepsian species in the Mediterranean Sea. Acta Parasitol. 51:22330.

Thiyagarajan, U, Harder, T, Qian, PU, 2003: Combined effect of temperature and salinity on larval development and attachment of the survival barnacle Balanus trigonus Darwin. J. Exp. Mar. Biol. Ecol. 28:223-6.

Waheed, M, Emam, MW, AbdEl-Halim, A, Saad, AA, Khalid, M, et al, 2013: Evaluation of water quality of Abu-Qir Bay, Mediterranean Coast, Egypt. Int. J. Environ. Sci. Eng. (IJESE), 4:47-54.

Youssef, ME, Salam, HN, Eissa, IAM, Zaki S M, 2014: Parasitological studies on the isopoda (Cymothoidae) parasites infesting some marine fishes at Suez Canal area at Ismailia Governorate, Egypt with a key to the Cymothoid genera. Life Sci. J. 11, 1:227-31.

\section{Explanation of figures}

Fig 1: Locations, B Boughaz Al Meadeyya, C Collection of Mugliid fry in fine mish net D Basin inside the Fry Collection Station. Fig 2: A dorsal and ventral aspect of $L$. redmanii juveniles; bar $1 \mathrm{~cm}$ B collected Mugliid fry samples

Chart 1: Effect of temperature, salinity and their interaction on percentage of survival of juvenile stage of L. redmanii

Chart 2: Mean survival of L. redmani juveniles at different temperature. 

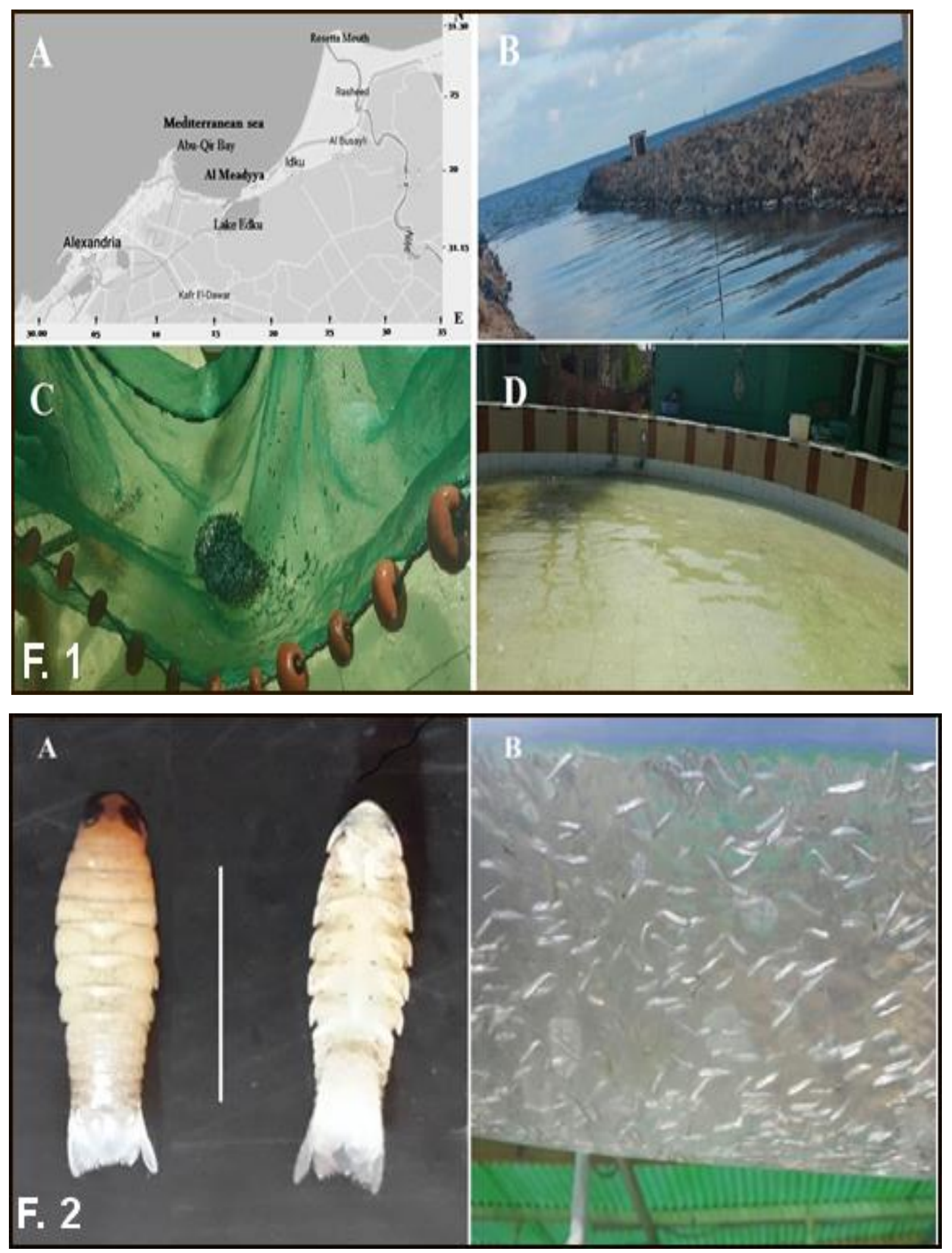

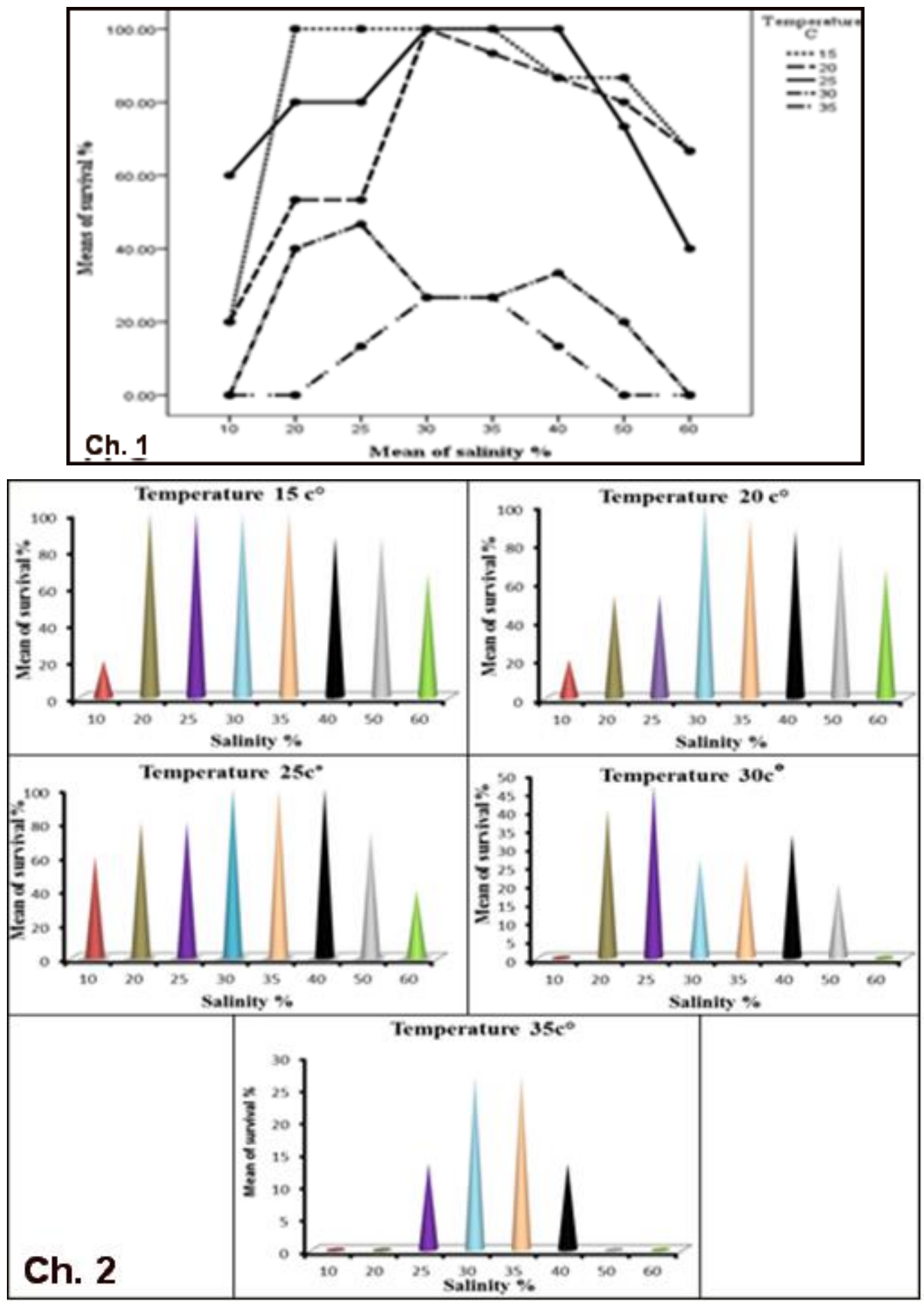